\title{
MATHEMATICAL PROBLEM-SOLVING STRATEGIES AMONG STUDENT TEACHERS
}

Melanie Guzman Gurat School of Teacher Education and Humanities / School of Graduate Studies, University Research Center, Saint Mary's University, Philippines, melanie.gurat@yahoo.com

Highlights
- $\quad$ Problem-solving strategies among student teachers are cognitive, metacognitive and other strategies
- Results indicate significant influence of the strategies on academic performance of the student teachers

\section{Abstract}

The main purpose of the study is to understand the mathematical problem-solving strategies among student teachers. This study used both quantitative and qualitative type of research. Aside from the semi-structured interviews, data were gathered through participant's actual mathematical problemsolving outputs and the videotaped interviews. Findings revealed that the problem-solving strategies among student teachers in the Problem-Solving subject are cognitive, metacognitive and other strategies. The cognitive strategies used by the student teachers are rehearsal, elaboration, and organization. The metacognitive strategies are critical thinking and self-regulation. Other strategies are overlapping the cognitive and metacognitive strategies. These are prediction/orientation, planning, monitoring, and evaluating. The findings also suggest significant influence of the strategies on the academic performance of the student teachers.

\section{Keywords}

Cognitive, critical thinking, elaboration, metacognitive, organization, rehearsal, self-regulation
Article type

Full research paper

Article history

Received: September 14, 2017

Received in revised form: August 29, 2018

Accepted: August 29, 2018

Available on-line: September 30, 2018

Guzman Gurat M. (2018) "Mathematical problem-solving strategies among student teachers", Journal on Efficiency and Responsibility in Education and Science, Vol. 11, No. 3, pp. 53-64, online ISSN 1803-1617, printed ISSN 2336-2375, doi: 10.7160/ eriesj.2018.110302.

\section{Introduction}

Problem-solving has a special importance in the study of mathematics (Wilson, Fernandez and Hadaway, 2011). The main goal in teaching mathematical problem-solving is for the students to develop a generic ability in solving real-life problems and to apply mathematics in real life situations. It can also be used, as a teaching method, for a deeper understanding of concepts. Successful mathematical problem-solving depends upon many factors and skills with different characteristics. One of the main difficulties in learning problem-solving is the fact that many skills are needed for a learner to be an effective problem solver. Also, these factors and skills make the teaching of problem-solving one of the most complex topics to teach (Dendane, 2009). Mathematics is used to quantify numerically and spatially natural as well as man-made situations. It is used to solve problems and it has helped in making social, economic and technological advances (Dendane, 2009).

Learning facts and contents in mathematics are important but these are not enough. Students should learn how to use these facts to develop their thinking skills in solving problems. Special attention for the development of problem-solving ability has been accepted by mathematics educators (Stanic and Kilpatrick, 1989) and genuine mathematical problemsolving is one of the most important components in any mathematics program or curriculum (Stacey, 2005; Halmos, 1980; Cockcroft, 1982). Mathematical problem-solving may help students to improve and develop the standard ability to solve real-life problems, (Reys et al. 2001), to develop critical thinking skills and reasoning, to gain deep understanding of concepts (Schoenfeld, 1992; Schoen and Charles, 2003) and to work in groups, cooperate with and interact with each other (Dendane, 2009). Specifically, it may also improve eagerness of an individual to try to analyze mathematical problems and to improve their determination and self-concepts with respect to the abilities to solve problems; make the individual aware of the problem-solving strategies, value of approaching problems in an orderly manner and that many problems can be solved in more than one way and; improve individuals' abilities to select appropriate solution strategies, capacity to implement solution strategies accurately and abilities to get a correct answers to problems (Hoon, Kee, and Singh, 2013).

A heuristic is a mathematical problem-solving strategy formulated in a free-of-context manner and done systematically (Koichu, Berman and Moore, 2004). Moreover, a heuristic approach can encourage connection of mathematical thoughts by examining special cases, drawing a diagram, specializing the solution, generalizing the solution (Hoon, Kee, and Singh, 2013). It is associated with non-routine mathematical problems such as looking backward or thinking forward (Koichu, Berman and Moore, 2004). Several studies were conducted to improve students' skills in solving mathematics problems. Hoon, Kee, Singh (2013) investigated students' response in applying heuristics approach in solving mathematical tasks, and their abilities in applying the heuristics approach. Reiss and Renkl (2002) proposed the use of heuristic worked-out examples in proving. They suggested that this should be integrated into mathematics classroom frequently so that students will learn to extract needed information in the problems. Novotná (2014) aimed to improve the pupils' culture of problem-solving through dealing with strategies such as analogy, guess-checkrevise, problem reformulation, solution drawing, systematic experimentation, way back and use of graphs of functions With the studies showing how strategies can improve mathematics problem solving, Koichu, Berman, and Moore (2004) aimed to promote heuristic literacy in a regular mathematics classroom. Moreover, Dewey's (1933) "How we think", Polya's (1988) problem-solving methods and the stages of Krulik and 
Rudnick's (1978) in solving were some of the theoretical bases in conducting this study (cited by Carson, 2007). These theories explained problem-solving as strategies in solving. Dewey's (1933) steps are confronting the problem, diagnosing or defining the problem, inventorying several solutions, conjecturing consequences of solutions and testing the consequences. On the other hand, Polya's (1988) stages consist of understanding the problem, devising a plan, carrying out the plan and looking back. Similarly, Krulik and Rudnick's (1978) procedures are reading, exploring, selecting a strategy, solving and reviewing and extending. These theories serve as a guide to a researcher to work on particular strategies performed by the student teachers while dealing with the mathematical problem-solving task. In this study, problem-solving refers to the common situational problems in mathematics in a form of problem set or worded problems. The problems are composed of items in arithmetic and algebra, trigonometry, geometry, sets, probability, number theory and puzzle problem/logic.

Hence, with the main goal of mathematics education to improve students' problem-solving skills in mathematics particularly to the student teachers who will be future mathematics educators, this study aimed to understand the mathematical problemsolving strategies among student teachers. This study can be used as a basis for the tertiary mathematics educators to determine different methods or interventions to improve the problem-solving skills of the future teachers so that they will be equipped with enough skills in teaching mathematics for their future students. It can also serve as a realization for them to grow more sensitive to different strategies and to realize that there are more strategies in solving problems in mathematics.

\section{Materials and Methods}

The study was qualitative. Semi-structured interviews, participant's actual mathematical problem-solving outputs, Filled-up Mathematics Motivated Strategies Learning Questionnaires (MMSLQ) by Liu and Lin (2010) (See Appendix A) and videotaped interviews were used to triangulate the gathered data. Techniques and analytical tools by Strauss and Corbin (1998) and the constant comparison method by Glaser and Strauss (1967) were used. The data used in the study was the initial process conducted to determine metacognitive strategy knowledge in the study of Gurat and Medula (2016). The identified strategies were used by Gurat and Medula in constructing a framework of metacognitive strategy knowledge in solving math problems. The participants of the study were the student teachers who were currently enrolled in ProblemSolving subject during the summer 2011 term. Student teachers are the senior college students of Saint Mary's University officially enrolled in Problem-Solving subject. The class is composed of 23 students, 19 of which are Bachelor of Elementary Education major in General Elementary Education (BEED - GEE), 4 Bachelor of Secondary Education major in Mathematics (BSED Math) and 1 Bachelor of Elementary Education major in General Science (BEED General Science), 19 females and 4 males. Out of 23 students, only 12 BEED GEE students were willing to be interviewed. Out of 19 females, there are only 10 females interviewed and out of 4 males, there are only 2 males interviewed. The scores of the student teachers in the Mathematics problem set or their grades in ProblemSolving subject were not used as a criterion for identifying the respondents to be interviewed. Table 1 shows the course and year, gender, grade in Problem-Solving subject and scores of interviewed and not interviewed student teachers in the given problem set and their grades in Problem-Solving subject.

\begin{tabular}{|c|c|c|c|c|}
\hline Name & $\begin{array}{c}\text { Course \& } \\
\text { Year }\end{array}$ & Gender & $\begin{array}{c}\text { Grade in } \\
\text { Problem-solving }\end{array}$ & $\begin{array}{c}\text { Score } \\
\text { (out of } 22 \text { points) }\end{array}$ \\
\hline \multicolumn{5}{|l|}{ Interviewed } \\
\hline Ana & BEED 4 & $\mathrm{~F}$ & 80 & 5 \\
\hline Barbara & BEED 4 & $\mathrm{~F}$ & 83 & 2 \\
\hline Carding & BEED 4 & M & 81 & 1 \\
\hline Clara & BEED 4 & $\mathrm{~F}$ & 85 & 3 \\
\hline Ester & BEED 4 & $\mathrm{~F}$ & 86 & 6 \\
\hline Grasya & BEED 4 & $\mathrm{~F}$ & 85 & 4 \\
\hline Helen & BEED 4 & $\mathrm{~F}$ & 89 & 8 \\
\hline Inday & BEED 4 & $\mathrm{~F}$ & 89 & 4 \\
\hline Isagani & BEED 4 & M & 95 & 9 \\
\hline Maria & BEED 4 & $\mathrm{~F}$ & 84 & 3 \\
\hline Selya & BEED 4 & $\mathrm{~F}$ & 86 & 4 \\
\hline Soledad & BEED 4 & $\mathrm{~F}$ & 89 & 5 \\
\hline \multicolumn{5}{|c|}{ Not Interviewed } \\
\hline Delya & BEED 4 & $\mathrm{~F}$ & 85 & 6 \\
\hline Elyas & BEED 4 & M & 77 & 5 \\
\hline Esteban & BEED 4 & $\mathrm{M}$ & 86 & 3 \\
\hline Fatima & BSED 4 & $\mathrm{~F}$ & 88 & 7 \\
\hline Julieta & BEED 4 & $\mathrm{~F}$ & 87 & 5 \\
\hline Katrina & BSED 4 & $\mathrm{~F}$ & 97 & 8 \\
\hline Lusing & BSED 4 & $\mathrm{~F}$ & 97 & 8 \\
\hline Nena & BESD 3 & $\mathrm{~F}$ & 94 & 12 \\
\hline Perla & BEED 4 & $\mathrm{~F}$ & 82 & 7 \\
\hline Tina & BEED 4 & $\mathrm{~F}$ & 87 & 6 \\
\hline Wilma & BEED 3 & $\mathrm{~F}$ & inc & 4 \\
\hline
\end{tabular}

Table 1: Course and year, gender, grade in Problem-Solving subject and scores of interviewed and not interviewed pre-service teacher education students

The instruments used in the study underwent tool validation and pilot testing. Revisions on the instruments were done before the student teachers were given the problem set (see Appendix B). The data gathering procedure started upon the approval to conduct this study. The student teachers answered the given set of problem-solving and the Mathematics Motivated Strategies Learning Questionnaires. The outputs of the students in the problem set and the result on the MMSLQ questionnaires were analyzed to construct the guide questions for the interview (see Appendix C). Semi-structured interviews were conducted at Roger Tjolle Building, second floor conference room of Saint Mary's University. The interviews were recorded and videotaped to validate/support interview responses. The interviews were transcribed and the transcriptions were analyzed through Strauss and Corbin coding process. In this stage, microanalysis was done which includes both open coding and axial coding. Then, related concepts were grouped together using axial coding. The categories formed were analyzed word-for-word, line-byline and sentence-by-sentence. Tables 2 and 3 show the sample excerpts from the open coding and axial coding respectively. Based on the concepts generated from the raw data, categories and subcategories were formed by constant comparison. Selective coding was also done to identify the themes formed from the axial coding. Finally, the result of the study was reported to student teacher for verification purposes. 


\begin{tabular}{|c|c|}
\hline English Translations & $\begin{array}{c}\text { Behaviors/ } \\
\text { Type of strategies } \\
\text { Sub categories/Others } \\
\end{array}$ \\
\hline $\begin{array}{l}\text { Mathematical problem solving is about } \\
\text { applying the formula and it is a systematic } \\
\text { process. So meaning it is a step-by-step } \\
\text { process to get the correct answer }\end{array}$ & $\begin{array}{l}\text { Systematic Approach (Monitoring) } \\
\text { Relate math to formulas }\end{array}$ \\
\hline $\begin{array}{l}\text { I use the formulas } \\
\text { (if familiar with the problem) }\end{array}$ & Use of formulas \\
\hline $\begin{array}{l}\text { If not, I analyze first the problem before } \\
\text { solving for the right answer. }\end{array}$ & Analysis of information \\
\hline $\begin{array}{l}\text { I read and understand it first then identify } \\
\text { the needed data }\end{array}$ & Read, analyze, solve method of solving \\
\hline $\begin{array}{l}\text { I set aside the problem then I will ask } \\
\text { for help from my classmate or I'll search } \\
\text { for problems that can be used to relate } \\
\text { to them }\end{array}$ & $\begin{array}{l}\text {-Categorize easy-hard question by skip- } \\
\text { ping items that are difficult to answer } \\
\text { (Organization) } \\
\text {-Looking Back at the problem } \\
\text {-Social } \\
\text {-relate to other problem (critical thinking) } \\
\text {-Speculation }\end{array}$ \\
\hline $\begin{array}{l}\text { I leave it ma'am, I do guessing but I feel } \\
\text { it's wrong If I really don't know it then } \\
\text { no more }\end{array}$ & $\begin{array}{l}\text {-guessing/trial and Error } \\
\text {-Explore/discover }\end{array}$ \\
\hline $\begin{array}{l}\text { It's like it's already in my mind like when } \\
\text { we have a lesson that I understood it so } \\
\text { I can imagine it. }\end{array}$ & $\begin{array}{l}\text {-recall lesson(rehearsal) } \\
\text {-analysis of information }\end{array}$ \\
\hline $\begin{array}{l}\text { During elementary, basic math was taught } \\
\text { to us. } \\
\text { Read what is the problem, and then first } \\
\text { you analyze it and find the given and then } \\
\text { identify the specific question asked in the } \\
\text { problem }\end{array}$ & $\begin{array}{l}\text {-systematic approach (monitoring) } \\
\text {-recall past lesson (rehearsal) } \\
\text {-analysis of information }\end{array}$ \\
\hline $\begin{array}{l}\text { I'm thinking about it, how I could answer } \\
\text { the given question }\end{array}$ & $\begin{array}{l}\text {-asking question (Elaboration) } \\
\text {-constructing meaning and developing an } \\
\text { interpretation }\end{array}$ \\
\hline $\begin{array}{l}\text { I read it first then I find ways to solve } \\
\text { what is being asked in the problem }\end{array}$ & $\begin{array}{l}\text {-exploring/discover } \\
\text {-critical thinking }\end{array}$ \\
\hline $\begin{array}{l}\text { Sometimes if I really don't know, I read it } \\
\text { again and again }\end{array}$ & $\begin{array}{l}\text {-reading repeatedly (rehearsal, prediction/ } \\
\text { orientation) } \\
\text {-Constructing meaning and developing an } \\
\text { interpretation }\end{array}$ \\
\hline $\begin{array}{l}\text { Hhmmm the questions seem like some- } \\
\text { thing given that...aaaayyyy I will think } \\
\text { how to solve it }\end{array}$ & $\begin{array}{l}\text {-explore/discover } \\
\text {-asking self (elaboration) }\end{array}$ \\
\hline
\end{tabular}

Table 2: Extract from open coding of interview transcripts

\begin{tabular}{|c|c|c|c|c|}
\hline What & $\begin{array}{l}\text { When does } \\
\text { the category } \\
\text { occur }\end{array}$ & $\begin{array}{l}\text { Why does } \\
\text { the category } \\
\text { occur }\end{array}$ & $\begin{array}{l}\text { How does the cat- } \\
\text { egory occur }\end{array}$ & Consequences \\
\hline $\begin{array}{l}\text { Constructing } \\
\text { meaning and } \\
\text { developing the } \\
\text { interpretation }\end{array}$ & $\begin{array}{l}\text { during the } \\
\text { first phase of } \\
\text { the problem } \\
\text { solving }\end{array}$ & $\begin{array}{l}\text { primary } \\
\text { encounter } \\
\text { and sense- } \\
\text { making }\end{array}$ & $\begin{array}{l}\text {-listing } \\
\text {-making drawing, } \\
\text { illustrations, tables, } \\
\text { chart } \\
\text {-reading the problem } \\
\text { again and again }\end{array}$ & $\begin{array}{l}\text { To understand } \\
\text { the problem }\end{array}$ \\
\hline $\begin{array}{l}\text { Analyzing } \\
\text { information }\end{array}$ & & & $\begin{array}{l}\text {-selecting relevant } \\
\text { information } \\
\text {-relating it to a cer- } \\
\text { tain mathematical } \\
\text { field }\end{array}$ & $\begin{array}{l}\text { To Analyze the } \\
\text { problem }\end{array}$ \\
\hline $\begin{array}{l}\text { Looking back } \\
\text { on the problem }\end{array}$ & & & $\begin{array}{l}\text { - recalling similar } \\
\text { problems } \\
\text {-assessing the degree } \\
\text { of difficulty }\end{array}$ & $\begin{array}{l}\text { To Analyze the } \\
\text { problem }\end{array}$ \\
\hline $\begin{array}{l}\text { Exploring/ } \\
\text { Discovering }\end{array}$ & $\begin{array}{l}\text { During } \\
\text { the second } \\
\text { phase of } \\
\text { the problem } \\
\text { solving }\end{array}$ & $\begin{array}{l}\text { Planning } \\
\text { what to do }\end{array}$ & $\begin{array}{l}\text {-Using trial and error } \\
\text {-visualizing the } \\
\text { situation } \\
\text {-establishing a con- } \\
\text { nection among part } \\
\text { of the problem } \\
\text {-analyzing the prob- } \\
\text { lem part by part }\end{array}$ & $\begin{array}{l}\text { Preparatory to } \\
\text { design a plan. } \\
\text { For better } \\
\text { analysis }\end{array}$ \\
\hline Speculating & & & $\begin{array}{l}\text { - relating it to real } \\
\text { life situation } \\
\text {-relating to a similar } \\
\text { problem encountered } \\
\text { before. }\end{array}$ & $\begin{array}{l}\text { Preparatory to } \\
\text { design a plan. } \\
\text { For better } \\
\text { analysis }\end{array}$ \\
\hline $\begin{array}{l}\text { Reflecting on } \\
\text { the discovery } \\
\text { and speculation }\end{array}$ & & & $\begin{array}{l}\text {-decision making } \\
\text { whether feasible } \\
\text { or not }\end{array}$ & Reflecting \\
\hline
\end{tabular}

Table 3: Extract from axial coding of interview transcripts

\section{Results}

Based on the transcriptions of the interviews, filled-up Mathematics Motivated Strategies Learning Questionnaires (MMSLQ) and scanned outputs in their actual problem-solving tasks, the strategies identified were cognitive, metacognitive and other strategies.

\section{Cognitive Strategies}

Three kinds of cognitive strategies were identified in this study. These include rehearsal, elaboration, and organization.

\section{Rehearsal}

Rehearsal is one of the cognitive strategies used by the student teachers in Summer 2011 Problem-Solving subject. Rehearsal is shown through re-reading the problem, solving problems repeatedly and recalling past lessons.

In addition, Table 4 shows the frequency and percent distribution of cognitive strategy of rehearsal used by the student teachers in solving mathematical problem-solving. The table reveals that the student teachers make use of the cognitive strategy of rehearsal since they responded that they sometimes or even always used their cognitive strategies. Only one respondent said that $\mathrm{s} /$ he repeatedly practice similar question types.

\begin{tabular}{|l|c|c|c|c|c|c|c|c|c|c|}
\hline & \multicolumn{2}{|c|}{$\begin{array}{c}\text { 1- never } \\
\text { or only } \\
\text { rarely } \\
\text { true in } \\
\text { me }\end{array}$} & \multicolumn{2}{|c|}{$\begin{array}{c}\text { 2- some- } \\
\text { times true } \\
\text { of me }\end{array}$} & $\begin{array}{c}\text { 3-true of } \\
\text { me about } \\
\text { half the } \\
\text { time }\end{array}$ & \multicolumn{2}{|c|}{$\begin{array}{c}\text { 4-frequent- } \\
\text { ly true of } \\
\text { me }\end{array}$} & \multicolumn{2}{|c|}{$\begin{array}{c}\text { 5- always } \\
\text { or almost } \\
\text { always } \\
\text { true of me }\end{array}$} \\
\cline { 2 - 13 } & $\mathbf{f}$ & $\mathbf{\%}$ & $\mathbf{f}$ & $\mathbf{\%}$ & $\mathbf{f}$ & $\%$ & $\mathbf{f}$ & $\%$ & $\mathbf{f}$ & $\%$ \\
\hline $\begin{array}{l}\text { I analyze the problem } \\
\text { again and again. }\end{array}$ & 0 & 0 & 0 & 0 & 7 & 30.44 & 8 & 34.78 & 8 & 34.78 \\
\hline $\begin{array}{l}\text { I repeatedly practice } \\
\text { similar question } \\
\text { types. }\end{array}$ & 1 & 4.35 & 2 & 8.70 & 11 & 47.83 & 7 & 30.44 & 2 & 8.70 \\
\hline $\begin{array}{l}\text { I study the class notes } \\
\text { and textbook again } \\
\text { and again. }\end{array}$ & 0 & 0 & 5 & 21.74 & 11 & 47.83 & 5 & 21.74 & 2 & 8.70 \\
\hline $\begin{array}{l}\text { I memorize the im- } \\
\text { portant and key math } \\
\text { formula to remind me } \\
\text { of the important part } \\
\text { of my math class }\end{array}$ & 0 & 0 & 4 & 17.39 & 6 & 26.09 & 9 & 39.13 & 4 & 17.39 \\
\hline $\begin{array}{l}\text { I do not forget prob- } \\
\text { lem-solving steps }\end{array}$ & 0 & 0 & 6 & 26.09 & 12 & 52.17 & 4 & 17.39 & 1 & 4.35 \\
\hline
\end{tabular}

Table 4: Frequency and percent distribution of the cognitive strategies of rehearsal used by the student teachers in solving mathematical problems

\section{Elaboration}

Elaboration was used by the student teachers in solving mathematical problems. This strategy was shown through underlining and selecting important details such as words and given in the problem and asking own self-questions related to solving. Table 5 shows that student teachers used elaboration in solving mathematical problems. If not sometimes true about half of the time or frequently, some also responded that they use it always. 


\begin{tabular}{|c|c|c|c|c|c|c|c|c|c|c|}
\hline \multirow[t]{2}{*}{$\begin{array}{l}\text { Cognitive Strate- } \\
\text { gies }\end{array}$} & \multicolumn{2}{|c|}{$\begin{array}{c}1-\text { never } \\
\text { or only } \\
\text { rarely } \\
\text { true in } \\
\text { me }\end{array}$} & \multicolumn{2}{|c|}{$\begin{array}{l}\text { 2- some- } \\
\text { times true } \\
\text { of me }\end{array}$} & \multicolumn{2}{|c|}{$\begin{array}{c}\text { 3- true of } \\
\text { me about } \\
\text { half the } \\
\text { time }\end{array}$} & \multicolumn{2}{|c|}{$\begin{array}{l}\text { 4-frequent- } \\
\text { ly true of } \\
\text { me }\end{array}$} & \multicolumn{2}{|c|}{$\begin{array}{c}\text { 5- always } \\
\text { or almost } \\
\text { always } \\
\text { true of me }\end{array}$} \\
\hline & $f$ & $\%$ & f & $\%$ & f & $\%$ & f & $\%$ & f & $\%$ \\
\hline $\begin{array}{l}\text { I ask questions to } \\
\text { myself to make } \\
\text { sure that I under- } \\
\text { stand the math } \\
\text { materials content }\end{array}$ & 0 & 0 & 4 & 17.39 & 9 & 39.13 & 7 & 30.43 & 3 & 13.04 \\
\hline $\begin{array}{l}\text { I link the class } \\
\text { notes to text- } \\
\text { book examples } \\
\text { to improve my } \\
\text { understanding. }\end{array}$ & 0 & 0 & 3 & 13.04 & 9 & 39.13 & 10 & 43.48 & 1 & 4.35 \\
\hline $\begin{array}{l}\text { I combine my own } \\
\text { known knowledge } \\
\text { with the learning } \\
\text { materials. }\end{array}$ & 0 & 0 & 2 & 8.70 & 10 & 43.48 & 9 & 39.13 & 2 & 8.70 \\
\hline $\begin{array}{l}\text { I do my best to } \\
\text { link relative por- } \\
\text { tions of math and } \\
\text { other subjects. }\end{array}$ & 1 & 4.35 & 2 & 8.70 & 12 & 52.17 & 8 & 34.78 & 0 & 0 \\
\hline $\begin{array}{l}\text { I will find out any } \\
\text { sample in daily life } \\
\text { to link with math } \\
\text { materials. }\end{array}$ & 0 & 0 & 4 & 17.39 & 15 & 65.22 & 4 & 17.39 & 0 & 0 \\
\hline
\end{tabular}

Table 5: Frequency and percent distribution of the cognitive strategies of elaboration used by the student teachers in solving a mathematical problem

\section{Organization}

The organization was shown by the student teachers by making connections between parts of the problem, making a drawing of the problem statement, and breaking down the problem into pieces, making simple charts/tables to better organize what is asked in the problem.

Problem solvers make connections between the parts of the problem in order to decide which of the following given are needed. They claim that if a solver did not get or understand the connection between parts of the problem he may fail to get the correct answer, especially that some problems have missing numbers needed to be solved first before solving what is really asked in the problem. It is also through making connections between parts of the problem that a problem solver may decide what strategy/formula/method/steps should fit the question. Furthermore, Figure 1 and 2 show the sample output revealing that student teachers make drawings.

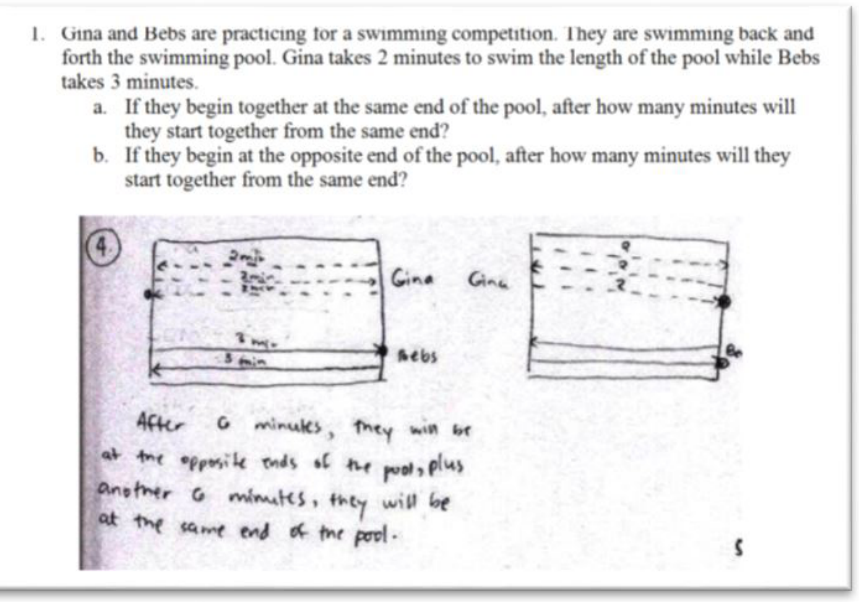

Figure 1: Drawing of Katrina
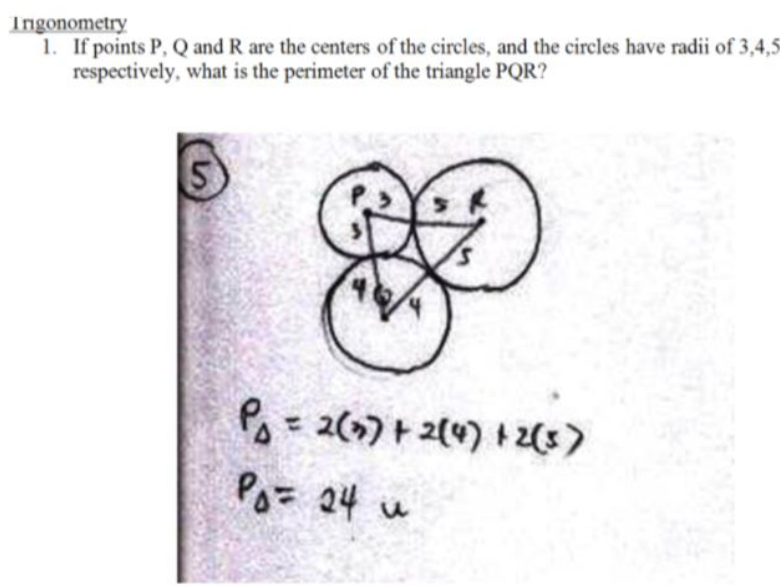

Figure 2: Drawing of Lusing

Making a drawing of the problem statement is evident especially if the given problem requires illustration before one can solve it. Examples are shown in Figures 1 and 2.

The organization can also be shown through making table.

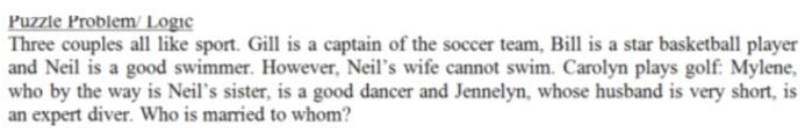

and Neil is a good swimmer. However, Neil's wife cannot swim. Carolyn plays golf: Mylene, who by the way is Neil's sister, is a good dancer and Jennelyn, whose husband is very short, is an expert diver. Who is married to whom?
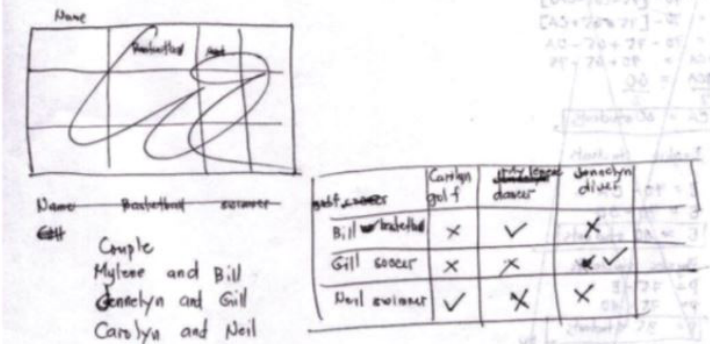

Figure 3: Table drawn by Helen

Figure 3 does not just reveal that student teachers make tables but it also shows the use of rehearsal. Helen draws table but disregarded it maybe because she repeats reading the problem. Though some respondents answered "no" when asked if they break down the problems into pieces, make simple charts/ tables to better organized what is asked in the problem, this is contradictory to their output revealing that the student teachers actually make charts/tables in answering a problem. One reason might be because the problem requires a solver to do so even if it is not written there that they must make table/charts. Thus, this also reveals that a solver may or may not be aware of their cognitive strategies.

In addition, Table 6 shows the frequency and percent distribution of cognitive strategy of organization used by the student teachers in solving mathematical problems. Only two respondents responded that they did not underline important words in the word problem but for the rest of the items, the table shows that they use the other strategies sometimes or even always. Thus, this shows that the student teachers used a cognitive strategy of the organization in solving. 


\begin{tabular}{|c|c|c|c|c|c|c|c|c|c|c|}
\hline \multirow[t]{2}{*}{$\begin{array}{l}\text { Cognitive Strat- } \\
\text { egies }\end{array}$} & \multicolumn{2}{|c|}{$\begin{array}{c}1-\text { never } \\
\text { or only } \\
\text { rarely } \\
\text { true in } \\
\text { me }\end{array}$} & \multicolumn{2}{|c|}{$\begin{array}{l}\text { 2- some- } \\
\text { times true } \\
\text { of me }\end{array}$} & \multicolumn{2}{|c|}{$\begin{array}{l}\text { 3- true of } \\
\text { me about } \\
\text { half the } \\
\text { time }\end{array}$} & \multicolumn{2}{|c|}{$\begin{array}{c}\text { 4-frequent- } \\
\text { ly true of } \\
\text { me }\end{array}$} & \multicolumn{2}{|c|}{$\begin{array}{l}\text { 5- always } \\
\text { or almost } \\
\text { always true } \\
\text { of me }\end{array}$} \\
\hline & $f$ & $\%$ & f & $\%$ & f & $\%$ & $\mathbf{f}$ & $\%$ & $f$ & $\%$ \\
\hline $\begin{array}{l}\text { I mark-up the } \\
\text { important lines } \\
\text { for concepts } \\
\text { organization. }\end{array}$ & 0 & 0 & 4 & 17.39 & 7 & 30.43 & 7 & 30.43 & 5 & 21.74 \\
\hline $\begin{array}{l}\text { I underline im- } \\
\text { portant words in } \\
\text { the word problem }\end{array}$ & 2 & 8.70 & 1 & 4.35 & 9 & 39.13 & 7 & 30.43 & 4 & 17.39 \\
\hline $\begin{array}{l}\text { I select relevant } \\
\text { numbers/data to } \\
\text { solve the problem }\end{array}$ & 0 & 0 & 2 & 8.70 & 6 & 26.09 & 10 & 43.48 & 5 & 21.74 \\
\hline $\begin{array}{l}\text { I adhere to the } \\
\text { plan systemati- } \\
\text { cally }\end{array}$ & 0 & 0 & 2 & 8.70 & 10 & 43.48 & 10 & 43.48 & 1 & 4.35 \\
\hline $\begin{array}{l}\text { I take time to } \\
\text { design an action } \\
\text { plan before actu- } \\
\text { ally calculating }\end{array}$ & 0 & 0 & 4 & 17.39 & 6 & 26.09 & 9 & 39.13 & 4 & 17.39 \\
\hline $\begin{array}{l}\text { I read through } \\
\text { the class notes } \\
\text { and textbook and } \\
\text { find out the most } \\
\text { important parts. }\end{array}$ & 0 & 0 & 4 & 17.39 & 6 & 26.09 & 9 & 39.13 & 4 & 17.39 \\
\hline $\begin{array}{l}\text { I read through } \\
\text { the class notes } \\
\text { and mark up the } \\
\text { important parts. }\end{array}$ & 0 & 0 & 4 & 17.39 & 9 & 39.13 & 7 & 30.43 & 3 & 13.04 \\
\hline $\begin{array}{l}\text { I categorize the } \\
\text { easy-hard type } \\
\text { questions of } \\
\text { every exam. }\end{array}$ & 0 & 0 & 4 & 17.39 & 7 & 30.43 & 9 & 39.13 & 3 & 13.04 \\
\hline $\begin{array}{l}\text { orderly take } \\
\text { note of problem- } \\
\text { solving steps }\end{array}$ & 0 & 0 & 4 & 17.39 & 11 & 47.83 & 5 & 21.74 & 3 & 13.04 \\
\hline $\begin{array}{l}\text { I make simple } \\
\text { charts and tables } \\
\text { to help me in or- } \\
\text { ganizing my math } \\
\text { class materials. }\end{array}$ & 0 & 0 & 1 & 4.35 & 11 & 47.83 & 9 & 39.13 & 2 & 8.70 \\
\hline $\begin{array}{l}\text { I select the } \\
\text { calculations that } \\
\text { will be needed to } \\
\text { solve the problem } \\
\text { and estimating } \\
\text { a possible out- } \\
\text { come }\end{array}$ & 0 & 0 & 3 & 13.04 & 10 & 43.48 & 3 & 13.04 & 7 & 30.43 \\
\hline $\begin{array}{l}\text { I act according to } \\
\text { the plan }\end{array}$ & 0 & 0 & 5 & 21.74 & 13 & 56.52 & 5 & 21.74 & 0 & 0 \\
\hline $\begin{array}{l}\text { I follow the } \\
\text { sequences of } \\
\text { problem-solving } \\
\text { steps orderly }\end{array}$ & 0 & 0 & 5 & 21.74 & 12 & 52.17 & 5 & 21.74 & 1 & 4.35 \\
\hline $\begin{array}{l}\text { I go over the } \\
\text { formula and im- } \\
\text { portant concepts } \\
\text { by myself. }\end{array}$ & 0 & 0 & 5 & 21.74 & 8 & 34.78 & 6 & 26.09 & 4 & 17.39 \\
\hline
\end{tabular}

Table 6: Frequency and percent distribution of the cognitive strategies of organization used by the student teachers in solving mathematical problems

\section{Meta-cognitive Strategies}

There are two types of metacognitive strategies revealed in this study. These are the critical thinking and self- regulation.

\section{Critical Thinking}

The critical thinking among student teachers was shown through having estimated outcome, relating problems in daily life, selecting or choosing only important numbers or details in a problem and asking one's self if the answer makes sense.

In addition, Table 7 shows the frequency and percent distribution of metacognitive strategy of critical thinking used by the student teachers in solving mathematical problem-solving. The table reveals that almost everyone used critical thinking in solving mathematical problem-solving. Only one among the 23 respondents claimed that s/he compares the difference between the teacher's explanation and textbook content and draw a conclusion referring to the task.

\begin{tabular}{|c|c|c|c|c|c|c|c|c|c|c|}
\hline \multirow[t]{2}{*}{$\begin{array}{l}\text { Metacognitive } \\
\text { Strategies }\end{array}$} & \multicolumn{2}{|c|}{$\begin{array}{l}\text { 1- never } \\
\text { or only } \\
\text { rarely } \\
\text { true in } \\
\text { me }\end{array}$} & \multicolumn{2}{|c|}{$\begin{array}{l}\text { 2- some- } \\
\text { times true } \\
\text { of me }\end{array}$} & \multicolumn{2}{|c|}{$\begin{array}{l}\text { 3- true of } \\
\text { me about } \\
\text { half the } \\
\text { time }\end{array}$} & \multicolumn{2}{|c|}{$\begin{array}{l}\text { 4-frequent- } \\
\text { ly true of } \\
\text { me }\end{array}$} & \multicolumn{2}{|c|}{$\begin{array}{l}\text { 5- always } \\
\text { or almost } \\
\text { always true } \\
\text { of me }\end{array}$} \\
\hline & f & $\%$ & $f$ & $\%$ & f & $\%$ & f & $\%$ & f & $\%$ \\
\hline $\begin{array}{l}\text { I usually question } \\
\text { what I heard or } \\
\text { what I learned } \\
\text { in math class, } \\
\text { and judge if this } \\
\text { information is } \\
\text { persuasive. }\end{array}$ & 0 & 0 & 6 & 26.09 & 8 & 34.78 & 7 & 30.43 & 2 & 8.70 \\
\hline $\begin{array}{l}\text { I make the math } \\
\text { class materials } \\
\text { as a start point } \\
\text { and try to self- } \\
\text { develop my own } \\
\text { viewpoint to the } \\
\text { topics. }\end{array}$ & 0 & 0 & 4 & 17.39 & 12 & 52.17 & 6 & 26.09 & 1 & 4.35 \\
\hline $\begin{array}{l}\text { I combine my } \\
\text { own idea into } \\
\text { the math class } \\
\text { learning. }\end{array}$ & 0 & 0 & 3 & 13.04 & 13 & 56.52 & 4 & 17.39 & 3 & 13.04 \\
\hline $\begin{array}{l}\text { I try to find out } \\
\text { another efficient } \\
\text { way to solve the } \\
\text { problem when } \\
\text { I hear some ideas } \\
\text { or some solutions. }\end{array}$ & 0 & 0 & 3 & 13.04 & 6 & 26.09 & 12 & 52.17 & 2 & 8.70 \\
\hline $\begin{array}{l}\text { I use a real } \\
\text { example to verify } \\
\text { the math theory } \\
\text { conclusion. }\end{array}$ & 0 & 0 & 6 & 26.09 & 10 & 43.48 & 6 & 26.09 & 1 & 4.35 \\
\hline $\begin{array}{l}\text { I compare the dif- } \\
\text { ference between } \\
\text { the teacher's } \\
\text { explanation and } \\
\text { textbook content. }\end{array}$ & 1 & 4.35 & 4 & 17.39 & 11 & 47.83 & 5 & 21.74 & 2 & 8.70 \\
\hline $\begin{array}{l}\text { I select relevant } \\
\text { materials to solve } \\
\text { the problem. }\end{array}$ & 0 & 0 & 1 & 4.35 & 14 & 60.87 & 5 & 21.74 & 3 & 13.04 \\
\hline $\begin{array}{l}\text { I make correct } \\
\text { use of units }\end{array}$ & 0 & 0 & 3 & 13.04 & 9 & 39.13 & 9 & 39.13 & 2 & 8.70 \\
\hline $\begin{array}{l}\text { I make notes } \\
\text { related to the } \\
\text { problem }\end{array}$ & 0 & 0 & 6 & 26.09 & 9 & 39.13 & 7 & 30.43 & 1 & 4.35 \\
\hline $\begin{array}{l}\text { I monitor the on- } \\
\text { going problem- } \\
\text { solving process } \\
\text { and change plan } \\
\text { if necessary }\end{array}$ & 0 & 0 & 4 & 17.39 & 10 & 43.48 & 9 & 39.13 & 0 & 0 \\
\hline $\begin{array}{l}\text { I summarize the } \\
\text { answer and reflect } \\
\text { on the answer }\end{array}$ & 0 & 0 & 6 & 26.09 & 9 & 39.13 & 7 & 30.43 & 1 & 4.35 \\
\hline $\begin{array}{l}\text { I draw a conclu- } \\
\text { sion referring to } \\
\text { the task }\end{array}$ & 1 & 4.35 & 5 & 21.74 & 10 & 43.48 & 4 & 17.39 & 3 & 13.04 \\
\hline $\begin{array}{l}\text { I relate a future } \\
\text { problems }\end{array}$ & 0 & 0 & 5 & 21.74 & 8 & 21.74 & 10 & 43.48 & 0 & 0 \\
\hline $\begin{array}{l}\text { I relate the given } \\
\text { problem to other } \\
\text { problems }\end{array}$ & 0 & 0 & 0 & 0 & 7 & 30.43 & 14 & 60.87 & 2 & 8.70 \\
\hline
\end{tabular}

Table 7: Frequency and percent distribution of the metacognitive strategies of critical thinking used by the student teachers in solving mathematical problems

\section{Self-regulation}

Student teachers reveal that they used self-regulation through answering the question, "how do you know that you have solved the problem correctly? What are your bases? And what makes you think it is correct?"

Student teachers associated getting the correct answer in checking their answers. If the answer matches with their checking, they are confident that the answer is correct. Some claim that they just know that it is correct because nothing is bothering them 
anymore or they are just confident that the answer is correct. Others just wait for the result if they are correct or not.

Table 8 shows the frequency and percent distribution of cognitive strategy of regulation used by the student teachers in solving mathematical problem-solving. The table reveals that almost all of student teachers responded sometimes true of me until always or almost true of me while few or almost nobody responded never or only rarely true in me. Thus, this shows that student teachers used their metacognitive strategies self-regulation in solving mathematical problems.

\begin{tabular}{|c|c|c|c|c|c|c|c|c|c|c|}
\hline \multirow[t]{2}{*}{$\begin{array}{l}\text { Metacognitive } \\
\text { Strategies }\end{array}$} & \multicolumn{2}{|c|}{$\begin{array}{l}\text { 1- never } \\
\text { or only } \\
\text { rarely } \\
\text { true in } \\
\text { me }\end{array}$} & \multicolumn{2}{|c|}{$\begin{array}{l}\text { 2- some- } \\
\text { times true } \\
\text { of me }\end{array}$} & \multicolumn{2}{|c|}{$\begin{array}{l}\text { 3- true of } \\
\text { me about } \\
\text { half the } \\
\text { time }\end{array}$} & \multicolumn{2}{|c|}{$\begin{array}{l}\text { 4-frequent- } \\
\text { ly true of } \\
\text { me }\end{array}$} & \multicolumn{2}{|c|}{$\begin{array}{c}\text { 5- always } \\
\text { or almost } \\
\text { always } \\
\text { true of me }\end{array}$} \\
\hline & f & $\%$ & f & $\%$ & f & $\%$ & f & $\%$ & f & $\%$ \\
\hline $\begin{array}{l}\text { I will go over to find } \\
\text { out where the prob- } \\
\text { lem is. }\end{array}$ & 0 & 0 & 3 & 13.04 & 12 & 52.17 & 8 & 34.78 & 0 & 0 \\
\hline $\begin{array}{l}\text { I set up my own } \\
\text { target and follow the } \\
\text { agenda I make. }\end{array}$ & 0 & 0 & 5 & 21.74 & 6 & 26.09 & 12 & 52.17 & 0 & 0 \\
\hline $\begin{array}{l}\text { I reorganize and } \\
\text { clarify the confused } \\
\text { points after class. }\end{array}$ & 1 & 4.35 & 5 & 21.74 & 6 & 26.09 & 7 & 30.43 & 4 & 17.39 \\
\hline $\begin{array}{l}\text { I check my answer } \\
\text { again after I finish the } \\
\text { question. }\end{array}$ & 0 & 0 & 2 & 8.70 & 9 & 39.13 & 7 & 30.43 & 5 & 21.74 \\
\hline $\begin{array}{l}\text { I list related formula } \\
\text { first. }\end{array}$ & 0 & 0 & 3 & 13.04 & 10 & 43.48 & 8 & 21.74 & 2 & 8.70 \\
\hline $\begin{array}{l}\text { When I make the } \\
\text { wrong math answers, } \\
\text { I will clarify whether } \\
\text { this conceptual } \\
\text { mistake or miscalcu- } \\
\text { lation. }\end{array}$ & 0 & 0 & 6 & 26.09 & 7 & 30.43 & 6 & 26.09 & 4 & 17.39 \\
\hline $\begin{array}{l}\text { I am correct in my } \\
\text { calculations }\end{array}$ & 0 & 0 & 6 & 26.09 & 11 & 47.83 & 6 & 26.09 & 0 & 0 \\
\hline $\begin{array}{l}\text { I check my calcula- } \\
\text { tions by calculating } \\
\text { again }\end{array}$ & 0 & 0 & 7 & 30.43 & 6 & 26.09 & 7 & 30.43 & 3 & 13.04 \\
\hline $\begin{array}{l}\text { I check the answer } \\
\text { with the estimated } \\
\text { outcome }\end{array}$ & 0 & 0 & 3 & 13.04 & 13 & 56.52 & 7 & 30.43 & 0 & 0 \\
\hline $\begin{array}{l}\text { I reflect on what went } \\
\text { well and how the } \\
\text { tasks were solved }\end{array}$ & 0 & 0 & 7 & 30.43 & 7 & 30.43 & 6 & 26.09 & 3 & 13.04 \\
\hline
\end{tabular}

Table 8: Frequency and percent distribution of the metacognitive strategies of self-regulation used by the student teachers in solving mathematical problems

\section{Other Strategies}

Other strategies were also revealed in this study such as prediction/orientation, planning, monitoring, and evaluating. These strategies were actually overlapping cognitive and metacognitive strategies discussed as classified by the action undertaken by student teachers as a part of the process of solving mathematical problems.

\section{Prediction/Orientation}

Prediction/orientation was revealed by the student teachers by analyzing the problem, again and again, underlining and selecting important details in the problem, drawing of the problem statement and having estimated outcomes which were categorized as rehearsal, elaboration, organization and critical thinking respectively. Prediction/orientation is shown through skipping difficult items and returning after solving the easy problems.

Moreover, Table 9 shows the frequency and percent distribution of prediction/orientation used by the student teachers in solving mathematical problem-solving. The table reveals that only one, two or nobody responded that they never used the other strategies presented to the student teachers. It also shows that only one or $4.35 \%$ responded to some selected items such as I underline important words in the word problem, I write down with my own words what I already knew, I have some idea or estimates of the possible outcomes, I select relevant steps to solve the problem, and two student teachers responded that they never underline important words in the word problem. Still, the majority responded that if not always, at least sometimes or even half of the time they used the other strategies presented in the table. Thus, this shows that student teachers use their other strategies of prediction/orientation.

\begin{tabular}{|c|c|c|c|c|c|c|c|c|c|c|}
\hline \multirow[t]{2}{*}{$\begin{array}{l}\text { Metacognitive } \\
\text { Strategies }\end{array}$} & \multicolumn{2}{|c|}{$\begin{array}{l}\text { 1- never } \\
\text { or only } \\
\text { rarely } \\
\text { true in } \\
\text { me }\end{array}$} & \multicolumn{2}{|c|}{$\begin{array}{l}\text { 2- some- } \\
\text { times true } \\
\text { of me }\end{array}$} & \multicolumn{2}{|c|}{$\begin{array}{c}\text { 3- true of } \\
\text { me about } \\
\text { half the } \\
\text { time }\end{array}$} & \multicolumn{2}{|c|}{$\begin{array}{l}\text { 4-frequent- } \\
\text { ly true of } \\
\text { me }\end{array}$} & \multicolumn{2}{|c|}{$\begin{array}{l}\text { 5- always } \\
\text { or almost } \\
\text { always } \\
\text { true of me }\end{array}$} \\
\hline & f & $\%$ & f & $\%$ & f & $\%$ & f & $\%$ & f & $\%$ \\
\hline $\begin{array}{l}\text { I underline important } \\
\text { words in the word } \\
\text { problem }\end{array}$ & 2 & 8.70 & 1 & 4.35 & 10 & 43.48 & 6 & 26.09 & 4 & 17.39 \\
\hline $\begin{array}{l}\text { I select the relevant } \\
\text { information needed } \\
\text { to solve the problem }\end{array}$ & 0 & 0 & 3 & 13.04 & 8 & 21.74 & 9 & 39.13 & 3 & 13.04 \\
\hline $\begin{array}{l}\text { I read the task again } \\
\text { to comprehend it } \\
\text { better }\end{array}$ & 0 & 0 & 3 & 13.04 & 5 & 21.74 & 7 & 30.43 & 8 & 21.74 \\
\hline $\begin{array}{l}\text { I write down with } \\
\text { my own words what } \\
\text { I already knew }\end{array}$ & 1 & 4.35 & 6 & 26.09 & 7 & 30.43 & 6 & 26.09 & 3 & 13.04 \\
\hline $\begin{array}{l}\text { I put the information } \\
\text { needed to solve the } \\
\text { problem together }\end{array}$ & 0 & 0 & 1 & 4.35 & 10 & 43.48 & 9 & 39.13 & 3 & 13.04 \\
\hline $\begin{array}{l}\text { I write down with my } \\
\text { own words what was } \\
\text { asked for }\end{array}$ & 1 & 4.35 & 5 & 21.74 & 9 & 39.13 & 4 & 17.39 & 4 & 17.39 \\
\hline $\begin{array}{l}\text { I reflect on the works } \\
\text { carefully and slowly } \\
\text { on difficult exercises } \\
\text { and fast on easy parts }\end{array}$ & 0 & 0 & 3 & 13.04 & 7 & 30.43 & 12 & 52.17 & 1 & 4.35 \\
\hline $\begin{array}{l}\text { I have some ideas or } \\
\text { estimates of the pos- } \\
\text { sible outcome }\end{array}$ & 1 & 4.35 & 3 & 13.04 & 10 & 43.48 & 9 & 39.13 & 0 & 0 \\
\hline $\begin{array}{l}\text { I select relevant steps } \\
\text { to solve the problem }\end{array}$ & 1 & 4.35 & 5 & 21.74 & 7 & 30.43 & 9 & 39.13 & 1 & 4.35 \\
\hline $\begin{array}{l}\text { I make a drawing } \\
\text { related to the problem }\end{array}$ & 0 & 0 & 2 & 8.70 & 7 & 30.43 & 10 & 43.48 & 4 & 17.39 \\
\hline
\end{tabular}

Table 9: Frequency and percent distribution of prediction/ orientation used by the student teachers in solving mathematical problems

\section{Planning}

Student teachers actually planned before solving the given problem. This was shown through the act of underlining or selecting important details, calculating or estimating outcome and others. These actions were also classified as elaboration and critical thinking respectively.

In addition, Table 10 shows the frequency and percent distribution of planning used by the student teachers in solving mathematical problem-solving. The table reveals that all of the student teachers responded sometimes true of me until always or almost true of me while few or almost nobody responded never or only rarely true in me. Thus, this shows that student teachers used their cognitive strategies of planning in solving mathematical problems. 
Guzman Gurat M. - ERIES Journal vol. 11 no. 3

\begin{tabular}{|l|c|c|c|c|c|c|c|c|c|c|c|}
\hline \multirow{2}{*}{ Other Strategies } & \multicolumn{2}{|c|}{$\begin{array}{c}\text { 1- never } \\
\text { or only } \\
\text { rarely } \\
\text { true in } \\
\text { me }\end{array}$} & \multicolumn{2}{|c|}{$\begin{array}{c}\text { 2- some- } \\
\text { times true } \\
\text { of me }\end{array}$} & \multicolumn{2}{|c|}{$\begin{array}{c}\text { 3-true of } \\
\text { me about } \\
\text { half the } \\
\text { time }\end{array}$} & \multicolumn{2}{|c|}{$\begin{array}{c}\text { 4-frequent- } \\
\text { ly true of } \\
\text { me }\end{array}$} & \multicolumn{2}{|c|}{$\begin{array}{c}\text { 5- always } \\
\text { or almost } \\
\text { always } \\
\text { true of me }\end{array}$} \\
\cline { 2 - 12 } f & $\%$ & f & $\%$ & f & $\%$ & f & $\%$ & f & $\%$ \\
\hline $\begin{array}{l}\text { I select relevant num- } \\
\text { bers/data to solve the } \\
\text { problem }\end{array}$ & 0 & 0 & 2 & 8.70 & 6 & 26.09 & 10 & 43.48 & 5 & 21.74 \\
\hline $\begin{array}{l}\text { I select the calcula- } \\
\text { tions that will be } \\
\text { needed to solve } \\
\text { the problem and to } \\
\text { estimate the possible } \\
\text { outcome }\end{array}$ & 0 & 0 & 3 & 13.04 & 11 & 47.83 & 3 & 13.04 & 6 & 26.09 \\
\hline $\begin{array}{l}\text { I select relevant } \\
\text { materials to solve the } \\
\text { problem. }\end{array}$ & 0 & 0 & 1 & 4.35 & 14 & 60.87 & 5 & 21.74 & 3 & 13.04 \\
\hline $\begin{array}{l}\text { I take time to design } \\
\text { an action plan before } \\
\text { actually calculating }\end{array}$ & 0 & 0 & 4 & 17.39 & 6 & 26.09 & 9 & 39.13 & 4 & 17.39 \\
\hline
\end{tabular}

Table 10: Frequency and percent distribution of planning used by the student teachers in solving mathematical problems

\section{Monitoring}

Through undergoing to the process, the student teachers strictly follow the whole step-by-step process. This is through solving repeatedly and remembering if they have encountered similar problems before. These were also classified as rehearsal. However, the student teachers also stated during the interview that they monitor their work to check progress, comprehension, and production.

In addition, Table 11 shows the frequency and percent distribution of monitoring used by the student teachers in solving mathematical problem-solving. The table reveals that only one responded never or rarely true of me in the item, I am correct in the calculation in using other strategies presented to the student teachers. It also shows that the student teachers sometimes used or always/almost used almost all of the other strategies showing monitoring presented to them. Thus, this shows that student teachers used monitoring in solving mathematical problems.

\section{Evaluation}

The student teachers who use metacognitive strategies such as organization, critical thinking, and elaboration also assess how well they accomplished their task of solving and how well they used learning strategies like making connections between parts of the problem; relating the problem in a sample in daily life and asking one's self if the answer makes sense; asking one's self some questions or talking to one's self; and checking answer respectively. These allow them to decide how effective the strategies were and to identify changes that they will make next time.

In addition, Table 12 shows the frequency and percent distribution of evaluation used by the student teachers in solving mathematical problem-solving. The table reveals that almost all used evaluation in solving mathematical problem solving except for the item on drawing a conclusion referring to the task.

\begin{tabular}{|c|c|c|c|c|c|c|c|c|c|c|}
\hline \multirow[t]{2}{*}{ Other Strategies } & \multicolumn{2}{|c|}{$\begin{array}{l}1-\text { never } \\
\text { or only } \\
\text { rarely } \\
\text { true in } \\
\text { me }\end{array}$} & \multicolumn{2}{|c|}{$\begin{array}{l}\text { 2- some- } \\
\text { times true } \\
\text { of me }\end{array}$} & \multicolumn{2}{|c|}{$\begin{array}{l}\text { 3- true of } \\
\text { me about } \\
\text { half the } \\
\text { time }\end{array}$} & \multicolumn{2}{|c|}{$\begin{array}{c}\text { 4-frequent- } \\
\text { ly true of } \\
\text { me }\end{array}$} & \multicolumn{2}{|c|}{$\begin{array}{r}\text { 5- always } \\
\text { or almost } \\
\text { always tru } \\
\text { of me }\end{array}$} \\
\hline & $\mathbf{f}$ & $\%$ & f & $\%$ & $\mathbf{f}$ & $\%$ & $\mathbf{f}$ & $\%$ & $\mathrm{f}$ & $\%$ \\
\hline $\begin{array}{l}\text { I adhere to the } \\
\text { plan systemati- } \\
\text { cally }\end{array}$ & 0 & 0 & 2 & 8.70 & 10 & 43.48 & 10 & 43.48 & 1 & 4.35 \\
\hline $\begin{array}{l}\text { I am correct in } \\
\text { my calculations }\end{array}$ & 1 & 4.35 & 5 & 21.74 & 11 & 47.83 & 6 & 26.09 & 0 & 0 \\
\hline $\begin{array}{l}\text { I make correct } \\
\text { use of units }\end{array}$ & 0 & 0 & 3 & 13.04 & 10 & 43.48 & 9 & 39.13 & 1 & 4.35 \\
\hline $\begin{array}{l}\text { I make notes } \\
\text { related to the } \\
\text { problem }\end{array}$ & 0 & 0 & 6 & 26.09 & 9 & 39.13 & 7 & 30.43 & 1 & 4.35 \\
\hline $\begin{array}{l}\text { I orderly take } \\
\text { note of problem- } \\
\text { solving steps }\end{array}$ & 0 & 0 & 4 & 17.39 & 11 & 47.83 & 5 & 21.74 & 3 & 13.04 \\
\hline $\begin{array}{l}\text { I do not forget } \\
\text { problem-solving } \\
\text { steps }\end{array}$ & 0 & 0 & 7 & 30.43 & 12 & 52.17 & 4 & 17.39 & 0 & 0 \\
\hline $\begin{array}{l}\text { I follow the } \\
\text { sequences of } \\
\text { problem-solving } \\
\text { steps orderly }\end{array}$ & 0 & 0 & 5 & 21.74 & 13 & 56.52 & 5 & 21.74 & 0 & 0 \\
\hline $\begin{array}{l}\text { I act according to } \\
\text { the plan }\end{array}$ & 0 & 0 & 5 & 21.74 & 13 & 56.52 & 5 & 21.74 & 0 & 0 \\
\hline $\begin{array}{l}\text { I monitor the on- } \\
\text { going problem- } \\
\text { solving process } \\
\text { and change plan } \\
\text { if necessary }\end{array}$ & 0 & 0 & 4 & 17.39 & 10 & 43.48 & 9 & 39.13 & 0 & 0 \\
\hline $\begin{array}{l}\text { I check my calcu- } \\
\text { lation calculating } \\
\text { again }\end{array}$ & 0 & 0 & 7 & 30.43 & 6 & 26.09 & 7 & 30.43 & 3 & 13.04 \\
\hline $\begin{array}{l}\text { I check the } \\
\text { answer with the } \\
\text { estimated out- } \\
\text { come }\end{array}$ & 0 & 0 & 3 & 13.04 & 13 & 56.52 & 7 & 30.43 & 0 & 0 \\
\hline $\begin{array}{l}\text { I reflect on the } \\
\text { answer and only } \\
\text { if all is checked } \\
\text { giving a clear, } \\
\text { exact and precise } \\
\text { answer }\end{array}$ & 0 & 0 & 4 & 17.39 & 11 & 47.83 & 8 & 21.74 & 0 & 0 \\
\hline
\end{tabular}

Table 11: Frequency and percent distribution of monitoring used by the student teachers in solving mathematical problems

\begin{tabular}{|c|c|c|c|c|c|c|c|c|c|c|}
\hline \multirow[t]{2}{*}{ Other Strategies } & \multicolumn{2}{|c|}{$\begin{array}{l}\text { 1- never } \\
\text { or only } \\
\text { rarely } \\
\text { true in } \\
\text { me }\end{array}$} & \multicolumn{2}{|c|}{$\begin{array}{l}\text { 2- some- } \\
\text { times true } \\
\text { of me }\end{array}$} & \multicolumn{2}{|c|}{$\begin{array}{c}\text { 3- true of } \\
\text { me about } \\
\text { half the } \\
\text { time }\end{array}$} & \multicolumn{2}{|c|}{$\begin{array}{l}\text { 4-frequent- } \\
\text { ly true of } \\
\text { me }\end{array}$} & \multicolumn{2}{|c|}{$\begin{array}{c}\text { 5- always } \\
\text { or almost } \\
\text { always } \\
\text { true of me }\end{array}$} \\
\hline & f & $\%$ & f & $\%$ & f & $\%$ & f & $\%$ & f & $\%$ \\
\hline $\begin{array}{l}\text { I summarize the } \\
\text { answer and reflect } \\
\text { on the answer }\end{array}$ & 0 & 0 & 6 & 26.09 & 9 & 39.13 & 7 & 30.43 & 1 & 4.35 \\
\hline $\begin{array}{l}\text { I reflect on what } \\
\text { went well and how } \\
\text { the tasks were solved }\end{array}$ & 0 & 0 & 7 & 30.43 & 7 & 30.43 & 6 & 26.09 & 3 & 13.04 \\
\hline $\begin{array}{l}\text { I draw a conclusion } \\
\text { referring to the task }\end{array}$ & 1 & 4.35 & 5 & 21.74 & 10 & 43.48 & 4 & 17.39 & 3 & 13.04 \\
\hline $\begin{array}{l}\text { I relate a future } \\
\text { problems }\end{array}$ & 0 & 0 & 5 & 21.74 & 8 & 21.74 & 10 & 43.48 & 0 & 0 \\
\hline $\begin{array}{l}\text { I relate the given } \\
\text { problem to other } \\
\text { problems }\end{array}$ & 0 & 0 & 0 & 0 & 7 & 30.43 & 14 & 60.87 & 2 & 8.70 \\
\hline
\end{tabular}

Table 12: Frequency and percent distribution of evaluation used by the student teachers in solving mathematical problems

\section{Discussion}

The student teachers' response to the questionnaire reveals that they used cognitive, metacognitive, other strategies for solving problems in mathematics. This was similar to the metacognitive strategy knowledge used in constructing a framework of metacognitive strategy knowledge of Gurat and Medula (2016) supported by Liu and Lin (2010) in their Mathematics Learning Strategies Scale. These strategies were also similar to the metacognitive and cognitive strategies found by Akyol, Sungur, and Tekkaya (2010) in science class. Other strategies such as 
prediction/orientation, planning, monitoring, and evaluation was also similar to Brown's (1978) four types of skills. Three kinds of cognitive strategies revealed were rehearsal, elaboration, and organization. These strategies were the same as the three of the five learning strategies described by Simsek (2006) as cited by Simsek and Balaban (2010). The rehearsal refers to the strategies such as rereading the problem, solving problems repeatedly and recalling past lessons to better understand the problem before trying to solve it. Student teachers took time in analyzing repeatedly which depends on the difficulty of the problem. This is similar to the comprehension monitoring of Schurter (2002) where readers of a mathematical problem must be able to comprehend the problem. However, some student teachers do not repeat solving the problem whenever they were given limited time. When student teachers were given parallel problems they repeatedly solved the problem using the same formula/method or they recalled the past lesson and applied the same method for attacking the problem. Another cognitive strategy was elaboration. Elaboration was shown through underlining and selecting important details such as words and given in the problem and asking own self-questions related to solving. Alternatives were also used by student teachers such as listing or singling out the important details or what they cannot understand. Student teachers asked themselves to identify if the given is connected with what is asked about the problem. Some of them asked themselves in their mind and others talked to themselves regarding the steps, if their answer was right or wrong, how they understood the problem or how they analyzed the problem. Lastly, the organization was also shown by making connections between parts of the problem, making a drawing of the problem statement, and breaking down the problem into pieces, making simple charts/tables to better organize what is asked in the problem. Problem solvers relate parts of the problem in order to decide which of the values in the given were needed or not. If a solver failed to connect the given, he might fail to get the correct answer, especially that some problems were tricky that missing numbers are needed to be solved first before solving for what was asked in the problem. Through this, the problem solver may decide what strategy/formula/method/steps should fit the question. Moreover, making a drawing of the problem statement was also evident especially if the given problem requires illustration before one can solve it. Drawing or making representation was one of the problem strategies of Hoon, Kee and Singh (2013) in learning mathematics and the solution drawing strategy and use of graphs of functions of Novotná, et al. (2014). Furthermore, the study Krawec et al. (2012) used the same term, cognitive strategy for improving math problem solving of middle school students with learning disabilities. However, their cognitive strategy was an intervention that motivated students to use several problem-solving strategies.

Two types of metacognitive strategies were critical thinking and self- regulation. The critical thinking among student teachers was shown through having estimated outcome, relating problems in daily life, selecting or choosing only important numbers or details in a problem and asking one's self if the answer makes sense. Problem solvers may or may not have estimated outcome depending on the depth of understanding of the problem. Some problems may not require the solution because it can be solved by relating the problem in real life. This strategy was similar to the concept of Goldman and Booker (2009) who used everyday practices in mathematics. In terms of self - regulation, student teachers checked their own answer. Some know that their answer was correct and others just wait for the result.

Other strategies were also revealed in this study such as prediction/orientation, planning, monitoring, and evaluating. These strategies overlap with the cognitive and metacognitive strategies. Prediction/orientation refers to analyzing the problem, again and again, underlining and selecting important details in the problem, drawing of the problem statement and having estimated outcomes which were categorized as rehearsal, elaboration, organization and critical thinking respectively. Planning refers to the act of underlining or selecting important details, calculating or estimating outcome and others. These actions were also classified as elaboration and critical thinking respectively. Monitoring refers to the systematic process of solving while solving repeatedly and remembering if they have encountered similar problems before. These were classified as rehearsal and were similar to the strategy of analogy of Novotná, et al. (2014). Solvers also checked progress, comprehension, and production. Lastly, evaluation refers to the assessment of accomplishment and decision on the effectiveness of strategies used.

The findings revealed that student teachers are applying the variety of problem-solving strategies in mathematics. Despite the strategies used, the result of the students in the mathematics problem set test did not show favorable scores even if the students obtained a grade of passing rating (77 to 97) in their Problem-Solving subject except for one student who incurred an incomplete (INC) mark. The strategies used by student teachers and their grades in Problem Solving subject suggest that these strategies are a contributory factor on the passing grades of the student teachers. This corroborates the result of the studies of Akyol, Sunur and Tekkaya (2010); and Simsek and Balaban (2010) on the significant contribution of metacognitive and cognitive strategies to students' achievement. However, when strategies are related to the scores in the given mathematics problem set, it contradicts the result of the studies of Akyol, Sunur and Tekkaya (2010); and Simyek and Balaban (2010).

\section{Conclusion}

The problem-solving strategies among student teachers officially enrolled in the Problem-Solving subject are cognitive, metacognitive and other strategies. Cognitive strategies used in problem-solving are rehearsal, elaboration, and organization Metacognitive strategies involved in problem-solving are critical thinking and self-regulation and other strategies involved are planning, monitoring, and evaluation. These strategies can be taught by the student teachers for their future students. It may also help their future students succeed in solving math problems by student teachers' prior knowledge and skills in strategies. The identified strategies could also be considered in making problem sets for the students for the improvement of the students. Future researchers can work on identifying the strategies that lead to correct answers and incorrect answers could be conducted to better understand how strategies in solving affect the students in understanding and answering mathematics problems. Since the result of this study suggests a positive influence of the strategies on the academic performance of the students, a more in-depth study using linear regression or correlations may be conducted to validate the result. They may also consider other factors that might affect students in solving mathematics problems such as student's attitudes, basic arithmetic skills, and retention to find the possible reason of the low scores of the student teachers when given mathematics problem set in different areas of math.

\section{Acknowledgment}

The author thanks Dr. Cesar T. Medula, Jr. her thesis adviser; Dr. Dominga C. Valtoribio, Dean of School of Graduate Studies, 
and to the distinguished panel members, namely: Dr. Moises Alexander T. Asuncion, Mrs. Analyn A. Guevara and Mr. Jay-ar Castriciones for their time, patience guidance, direction, interest and encouragements in the completion of this research.

\section{References}

Akyol, G., Sungur, S. and Tekkaya, C. (2010) 'The contribution of cognitive and metacognitive strategy use to students' science achievement', Educational Research and Evaluation, Vol. 16, No. 1, pp. 1-21. https://doi.org/10.1080/13803611003672348 Brown, A.L. (1978) 'Knowing when, where, and how to remember: A problem of metacognition', In Glaser, R. (ed) Advances in Instructional Psychology, Vol. 1. Hillsdale, NJ: Lawrence Erlbaum Associates, [Online], Available: http://www. eric.ed.gov/PDFS/ED146562.pdf [7 Jun 2011].

Carson, J. (2007) 'A problem with problem-solving: teaching thinking without teaching knowledge', The Mathematics Educator, Vol. 17, No. 2, pp. 7-14.

Cockcroft, W. (1982) Mathematics counts. Report of the committee of inquiry into the teaching of mathematics in schools, London: Her Majesty's Stationery Office, (ED.), [Online], Available: http://www.educationengland.org.uk/documents/ cockcroft/ [10 Jul 2011].

Dendane, A. (2009) 'Skills needed for mathematical problem solving', [Online], Available: http://www.analyzemath.com/ math_problems/paper_7.html [3 Apr 2011].

Dewey, J. (1933). 'How we think', Boston: D.C. Heath.

Glaser, B.G., and Strauss, A.L. (1967) 'The discovery of grounded theory: Strategies for qualitative research', Chicago: Aldine.

Goldman, S. and Booker, A. (2009) 'Making math a definition of the situation: Families as sites for mathematical practices', Anthropology and Education Quarterly, Vol. 40, No. 4, pp. 369387. https://doi.org/10.1111/j.1548-1492.2009.01057.x

Gurat, M. and Medula, C. Jr. (2016) 'Metacognitive strategy knowledge use through mathematical problem solving amongst student teachers', American Journal of Educational Research, Vol. 4, No. 2, pp. 170-189. https://doi.org/10.12691/ education-4-2-5

Halmos, P. (1980) 'The heart of mathematics', American Mathematical Monthly, Vol. 87, No. 7, pp. 519-524. https://doi. org/10.2307/2321415

Hoon, T., Kee K. and Singh, P. (2013) 'Learning mathematics using heuristics approach', Procedia - Social and Behavioral Sciences, Vol. 90, pp. 862-869. http://dx.doi.org/10.1016/j. sbspro.2013.07.162

Koichu, B., Berman, A. and Moore, M. (2004) 'Promotion of heuristic literacy in a regular mathematics classroom', For the Learning of Mathematics, Vol. 24, No. 1, pp. 33-39.

Krawec, J., Huang, J., Montague, M., Kressler, B. and de Alba, A. (2012) 'The effects of cognitive strategy instruction on knowledge of problem-solving processes of middle school students with learning disabilities', Learning Disability Quarterly, Vol. 36, No. 2, pp. 80-92. http://dx.doi.org/10.1177/0731948712463368 Krulik, S., and Rudnick, J.A. (1987) 'Problem solving: A handbook for teachers', (2nd ed.). Boston: Allyn and Bacon. Liu, E. and Lin C. (2010) 'The survey study of mathematics motivated strategies for learning questionnaire (MMSLQ) for grade 10-12 Taiwanese', The Turkish Online Journal of Educational Technology, Vol. 9, No. 2, pp. 221-223.

Novotná, J., Eisenmann, P., Přibyl, J., Ondrušová, J. and Břehovský, J. (2014) 'Problem solving in school mathematics based on heuristic strategies', Journal on Efficiency and
Responsibility in Education and Science, Vol. 7, No. 1, pp. 1-6. https://doi.org/10.7160/eriesj.2013.070101

Polya, G. (1988) 'How to solve it: A new aspect of mathematical method', (2nd ed.), Princeton, NJ: Princeton University Press.

Reiss, K. and Renkl, A. (2002) 'Learning to prove: The idea of heuristic examples', Zentralblatt für Didaktik der Mathematik (ZDM), Vol. 34, No. 1, pp. 29-35. https://doi.org/10.1007/ BF02655690

Reys, E, Lindquist, Lambdin D.V., Smith, N.L. and Suydam, M.N. (2001) 'Helping children learn mathematics', (6th ed.), John Wiley and Sons, Inc., New York.

Schoen, H.L. and Charles, R. I. (2003) 'Teaching mathematics through problem solving', National Council of Teachers of Mathematics (NCTM) catalog.

Schoenfeld, A. (1992) 'Learning to think mathematically: Problem-solving, metacognition, and sense making in mathematics', In D.A. Grouws (Ed.), Handbook of Research on Mathematics Teaching and Learning (pp. 165-197). MacMillan, New York.

Schurter, W. (2002) 'Comprehension monitoring: an aid to mathematical problem solving', Journal of Developmental Education, Vol. 26, No. 2, pp. 22-33.

Simsek, A. and Balaban, J. (2010) 'Learning strategies of successful and unsuccessful university students', Contemporary Educational Technology, Vol. 1. No. 1, pp. 36-45.

Simsek, A. (2006) 'Bilissel stratejilerin ogretimi [Teaching cognitive strategies]', In A. Simsek (Ed.), Icerik turlerine dayali ogretim (pp.181-208). Ankara: Nobel.

Stacey, K. (2005) 'The place of problem solving in contemporary mathematics curriculum documents', The Journal of Mathematical Behavior, Vol. 24, pp. 341. https://doi. org/10.1016/j.jmathb.2005.09.004

Stanic, G. and Kilpatrick, J. (1989) 'Historical Perspective on Problem Solving in the Mathematics Curriculum', In R. Charles and E. Silver (Eds.), The teaching and assessing of mathematical problem solving (pp. 1-22), Reston, VA: National Council of Teachers of Mathematics.

Strauss, A., and Corbin, J. (1998) 'Basics of Qualitative Research: Grounded theory procedures and techniques', (2nd ed.). London: Sage.

Wilson J., Fernandez M. and Hadaway, N. (2011) 'Mathematical problem solving', [Online], Available: http://jwilson.coe.uga. edu/emt725/PSsyn/Pssyn.html [8 Aug 2011]. 
Appendix A

Mathematics Questionnaires

Motivated

Strategies

Learning

Name:

This questionnaire has a number of questions about your metacognitive strategy knowledge.

There are many different strategies that good problem solvers use to solve a problem. It depends on the strategy which you may and may not be aware of.

Rate yourself by checking the box which you think is the most appropriate to you. Numbers below correspond to the following response.

1 - never or only rarely true in me

2- sometimes true of me

3- true of me about half the time

4- frequently true of me

5- always or almost always true of me

Do not spend a long time on each item; your first reaction is probably the best one. Please answer each item. Do not worry about projecting a good image. Your answers are CONFIDENTIAL.

Be honest as you are in choosing the answer. This is not an evaluation.

\begin{tabular}{|c|c|c|c|c|c|c|}
\hline No. & Statement & 1 & 2 & 3 & 4 & 5 \\
\hline A. & Before I begin, solving a problem, & & & & & \\
\hline 1 & I analyze the problem again and again. & & & & & \\
\hline 2 & I mark-up the important lines for concepts organization. & & & & & \\
\hline 3 & I underline important words in the word problem & & & & & \\
\hline 4 & I select relevant numbers/data to solve the problem & & & & & \\
\hline 5 & I adhere to the plan systematically & & & & & \\
\hline 6 & I relate the given problem to other problems & & & & & \\
\hline 7 & I take time to design an action plan before actually calculating & & & & & \\
\hline 8 & I have some idea or estimates the possible outcome & & & & & \\
\hline 9 & $\begin{array}{l}\text { I compare the difference between the teacher's explanation } \\
\text { and textbook content. }\end{array}$ & & & & & \\
\hline 10 & $\begin{array}{l}\text { I ask questions to myself to make sure that I understand the } \\
\text { math materials content }\end{array}$ & & & & & \\
\hline 11 & I repeatedly practice similar question types. & & & & & \\
\hline 12 & I study the class notes and textbook again and again. & & & & & \\
\hline 13 & $\begin{array}{l}\text { I make the math class materials as a start point and try to self- } \\
\text { develop my own viewpoint to the topics. }\end{array}$ & & & & & \\
\hline 14 & I reorganize and clarify the confused points after class. & & & & & \\
\hline 15 & $\begin{array}{l}\text { I try searching for patterns or symmetry in order to find the } \\
\text { correct answer like thinking of an easier problem than doing } \\
\text { the given task. }\end{array}$ & & & & & \\
\hline 16 & I read the task again to comprehend it better & & & & & \\
\hline 17 & I select relevant materials to solve the problem. & & & & & \\
\hline 18 & I make notes related to the problem & & & & & \\
\hline 19 & I write down with own words what was asked for & & & & & \\
\hline 20 & I select the relevant information needed to solve the problem & & & & & \\
\hline 21 & I combine my own idea into the math class learning. & & & & & \\
\hline 22 & $\begin{array}{l}\text { I memorize the important and key math formula to remind me } \\
\text { of the important part of my math class }\end{array}$ & & & & & \\
\hline 23 & $\begin{array}{l}\text { I link the class notes to textbook examples to improve my un- } \\
\text { derstanding. }\end{array}$ & & & & & \\
\hline 24 & $\begin{array}{l}\text { I read through the class notes and textbook and find out the } \\
\text { most important parts. }\end{array}$ & & & & & \\
\hline 25 & I read through the class notes and mark up the important parts. & & & & & \\
\hline 26 & I categorize the easy-hard type questions of every exam. & & & & & \\
\hline 27 & $\begin{array}{l}\text { I try to find out another efficient way to solve the problem } \\
\text { when I hear some idea or some solution. }\end{array}$ & & & & & \\
\hline 28 & I set up my own target and follow the agenda I make. & & & & & \\
\hline 29 & I list related formula first. & & & & & \\
\hline 30 & I divide the problems into parts or I solve in general. & & & & & \\
\hline 31 & I write down with own words what is already know & & & & & \\
\hline 32 & I select relevant steps to solve the problem & & & & & \\
\hline 33 & I orderly take note of problem-solving steps & & & & & \\
\hline 34 & I relate a future problems & & & & & \\
\hline 35 & I make a drawing related to the problem & & & & & \\
\hline
\end{tabular}

\begin{tabular}{|l|l|}
\hline 36 & I put the information needed to solve the problem together \\
\hline
\end{tabular} \begin{tabular}{lll}
\hline B. & While solving the problem, \\
\hline
\end{tabular}

37 I usually question what I heard or what I earn in math class, and judge if this information is persuasive.

\begin{tabular}{l|l}
38 & I know how and when to add, subtract, multiply and divide.
\end{tabular}

39 I used trial and error when I don't know the formula of the 39 problem.

\begin{tabular}{|l|l}
\hline 40 & I have my own tactics in solving a problem
\end{tabular}

41 In order to get the right answer, I have to follow the method $41 \quad$ step by step.

42 I combine my own known knowledge with the learning ma42 terials.

43 I make simple charts and tables to help me in organizing my 43 math class materials.

44 I am aware of what „borrowing“ means in subtracting num44 bers.

45 I select the calculations that will be needed to solve the prob-

45 lem and estimating a possible outcome

46 I visualize the scenario in the problem by drawing, hoping to

46 see what is really asked about the problem.

47 I know how to manipulate the general formula to arrive at 47 a certain formula on getting what is missing in the problem.

48 I use arithmetic in solving the problem.

49 I know what "carrying" means is in addition and how to use it.

50 I use strategies which provide a definite and certain way to $50 \quad$ reach a goal.

I try using different strategies like guess and check, diagrams

51 and others in solving problems trying to bring out the answer even if I am not sure.

52 I act according to the plan

53 I am correct in my calculations

54 I reflect on works carefully and slowly on difficult exercises

54 and fast on easy parts

55 I make correct use of units

56 I do not forget problem-solving steps

\begin{tabular}{lll} 
I follow the sequences of problem-solving steps orderly \\
\hline
\end{tabular}

58 I monitor the on-going problem-solving process and change plan if necessary

C. After I've arrived at the answer,

59 I do my best to link relative portions of math and other sub-

59 jects.

$\begin{array}{ll}60 & \text { I go over to find out where the problem is. }\end{array}$

61 I summarize the answer and reflecting on the answer

62 I reflect on the answer and only if all is checked giving a clear,

62 exact and precise answer

63 When I make the wrong math answers, I will clarify whether

63 this is a conceptual mistake or miscalculation.

64 I draw a conclusion referring to the task

\begin{tabular}{|l|l}
\hline 65 & I reflect on what went well and how the tasks were solved
\end{tabular}

66 I check my calculation calculating again

67 I check my answer again after I finish the question.

68 I use a real example to verify the math theory conclusion.

69 I go over the formula and important concepts by myself.

\begin{tabular}{l|l}
70 & I find out any sample in daily life to link with math materials.
\end{tabular}

71 I check the answer with the estimated outcome

\begin{tabular}{l|l}
\hline 72 & I repeatedly practice similar question types. \\
\hline
\end{tabular} 
Appendix B

\section{Mathematical Problem Solving Set}

Arithmetic

1. After the first 57 games of the UAAP season, the Blue Eagles have a winning percent of 0.561 and the Green Archers have a winning percent of 0.491. How many games behind the Blue Eagles are the Green Archers? (1pt)

2. If $\mathrm{x}$ is divided by 9 , the remainder is 5 . What is the remainder if $3 \mathrm{x}$ is divided by 9 ? $(1 \mathrm{pt})$

$\underline{\text { Algebra }}$

3. The principal in a school decided that the number of scouts who could go camping would be greater than or equal to 100 but less than or equal to 140 . She further wanted 2/7 to be from the fourth year scout and the rest would come in equal number from first, second and third year scouts.

a. What minimum number of scouts from each year of the lower years could go? What is the maximum number?(2 pts)

b. What is the minimum number of fourth year scouts that could go? What is the maximum number? (2 pts)

4. Gina and Bebs are practicing for a swimming competition. They are swimming back and forth to the swimming pool. Gina takes 2 minutes to swim the length of the pool while Bebs takes 3 minutes.

a. If they begin together at the same end of the pool, after how many minutes will they start together from the same end? (1 pt)

b. If they begin at the opposite end of the pool, after how many minutes will they start together from the same end? (1 pt)

Trigonometry

5. If points $\mathrm{P}, \mathrm{Q}$ and $\mathrm{R}$ are the centers of the circles, and the circles have radii of $3,4,5$ respectively, what is the perimeter of the triangle $\mathrm{PQR}$ ? (1 pt)

\section{Geometry}

6. Most proofs are done by means of deduction: that is we proceed from the premises, step by step, to a conclusion. As we go from one step to the next step, we must have a reason for each step to show that it follows logically. The following is an example of the proof that does not obey the rules: even though the desertion appears to be correct, it is not. Can you find the error? (1 pt)

\begin{tabular}{|c|c|c|}
\hline \multicolumn{2}{|r|}{ Statements } & \multirow[t]{2}{*}{ Reasons } \\
\hline & $\mathrm{a}=\mathrm{b}$ & \\
\hline & $a^{2}=a b$ & Multiplying Both sides by a \\
\hline 3. & $a^{2}-b^{2}=a b-b^{2}$ & Subtracting b2 from both sides \\
\hline & $(a+b)(a-b)=b(a-b)$ & Factoring both sides \\
\hline & $\frac{(a+b)(a-b)=b(a-b)}{a-b}$ & Dividing both sides by $a-b$ \\
\hline & $(a+b)=b$ & Result of Step 5 \\
\hline 7. & $\mathrm{~b}+\mathrm{b}=\mathrm{b}$ & Substituting $\mathrm{b}$ for $\mathrm{a}$ \\
\hline & $2 b=b$ & Combines $\mathrm{b}+\mathrm{b}$ \\
\hline 9. & $2 b / b=b / b$ & Dividing both sides by $\mathrm{b}$ \\
\hline 10. & $2=1$ & Result for step 9 \\
\hline
\end{tabular}

Q.E.D.

$\underline{\text { Sets }}$

7. Consider the given information on the right regarding the number of enrolled students in three major subjects such as College Algebra, Physics, and English 1a. There are 350 students enrolled in these subjects. 65 of which are enrolled both in Physics and College Algebra, 70 of which are enrolled both in College
Algebra and English 1a and 75 of which are enrolled both in Physics and English 1a.

a. How many students are enrolled in College Algebra? (1 pt)

b. What is the total number of students enrolled in English 1a? (1 pt)

c. The number of students enrolled in Physics 1 is ( $(1 \mathrm{pt})$

d. The total number of students enrolled in Physics 1 and College Algebra is $(1 \mathrm{pt})$

e. How many students are enrolled in Physics 1a and College Algebra but not enrolled in both subjects? (1 pt)

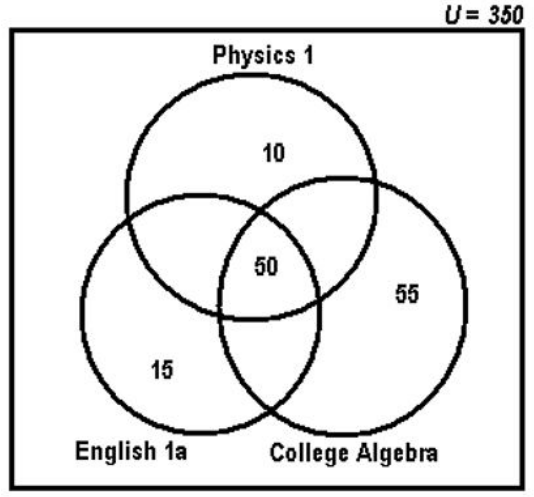

Probability

8. In how many ways can 3 boys and 3 girls be seated in a row if:

a. They may sit anywhere? (1 pt)

b. The girls and boys must alternate? (1 pt)

Number Theory

9. What is the maximum number of positive consecutive integers that can be added together before the sum exceeds 5 000? (1 pt)

\section{Puzzle Problem/Logic}

10. Three couples all like sport. Gill is a captain of the soccer team, Bill is a star basketball player and Neil is a good swimmer. However, Neil's wife cannot swim. Carolyn plays golf: Mylene, who by the way is Neil's sister, is a good dancer and Jennelyn, whose husband is very short, is an expert diver. Who is married to whom? (3 pts) 


\section{Appendix C}

\section{Semi-Structured Interview Protocol}

Introduction:

Hi, I'm Ms. Melanie G. Gurat. I am so glad you have decided to participate in this study. The purpose of this project is to better understand your thinking in Mathematical Problem Solving.

And I want you to feel free in using the dialect in answering each question. The answers that you will give in this interview will help a lot in my research so please do not hesitate to answer them as honestly as you can. If I stop you from asking a question, I am not actually disagreeing but only trying to gain a better understanding of the way you think about some things. I'll be recording and videotaping this interview and transcribing it, but the information you will share with me will be strictly confidential. The answers you will give in this interview will not affect your class evaluation. If there are questions that are not clear to you, feel free to ask me. Do you have any questions? (There will be pre-interview questions to be asked to establish rapport with the students and let them feel comfortable with the researcher.)

Interview Questions:

1. What do you know about mathematical problemsolving?

2. How do you solve mathematical problems?

Probing Question if in case the answer of the respondent is more technical: What are the processes you usually use in solving math problems?

a. If you are familiar with the problem? (you know the formula)

b. The problem is new to you or you are not familiar?

3. What is the first thing you do?

a. Do you analyze the problem again and again?

b. Do you make connections between parts of the problem? When? Why?

c. Do you underline and select important details such as words and given numbers? Do you usually use all the information in the problem to solve what is unknown? When? Why?

4. How do you know you have understood the problem?

a. Do you master the problem by solving the problem repeatedly?

b. Do you make a drawing of the problem statement?

c. Do you have an estimated outcome?

d. Do you relate the problem in the sample in daily life?

5. Do you also try using different strategies in solving varied mathematical investigation problems?? What are those strategies? Why do you prefer to use them?

6. How do you select a strategy in solving a specific problem?

a. Do you try to remember whether you had worked on the problem similar to this before?

b. Do you ask yourself other questions to understand the problem? What are those questions? Why do you ask such questions? Do you usually ask questions or talk to yourself throughout the problem-solving process?

c. Do you break down the problem into pieces, make simple charts/tables to better organize what is asked in the problem?

7. Do you usually use all the information in the problem to solve what is unknown? Why?
8. Once you have arrived at an answer, what do you usually do? How often? Why?

a. Do you check your answer again?

i. Do you look back

ii. Do you substitute your answer with the formula/ recheck the algorithmic computations

iii. Verify it using other strategies?

b. Do you ask yourself if your answer makes sense?

9. How do you know you have solved the problem correctly? What are your bases? What makes you think it is already correct?

10. Any concluding statements regarding your experience in solving mathematical investigation problems

a. During solving the problem, and you encountered difficulty (describe the character of difficulty)

b. During solving the problem, you found a mistake and corrected it (describe the mistake)

Note: Probing questions will depend on students' responses on each question above. 